\title{
The earthquake of 1926 in Padang Panjang, West Sumatra
}

\author{
Yenny Narny ${ }^{1^{*}}$, Robert $\mathrm{Cribb}^{2}$, Yudhi Andoni ${ }^{1}$, and Ifkar Fikri ${ }^{1}$ \\ ${ }^{1}$ Department of History, Andalas University 25163 Padang, West Sumatera Indonesia \\ ${ }^{2}$ Department of Political and Social Change, Coral Bell School of Asia-Pacific Affairs, Australian National University, \\ Canberra-Australia
}

\begin{abstract}
This study explores contemporary newspaper narratives on the devastation caused by the earthquake of 1926 in Padang Panjang, West Sumatra. These narratives become crucial amid the difficulty of finding historical statistical data for disaster studies that depict the chaotic situation caused by natural disasters in the past. Historical methods and methodologies were used in this study to combine fragments of information found in contemporary newspapers, especially those discussing the situation of societies and the policies of the Dutch colonial government in dealing with the earthquake of 1926 in Padang Panjang. This study hopefully opens new insights for the development of disaster disciplines and provides access to the development of the study of the history of disasters in developing countries, particularly in Indonesia.
\end{abstract}

\section{Introduction}

An earthquake is a natural disaster that is characterized by the intense vibration or shaking of the earth's surface in the outermost layer. Severe earthquakes cause enormous damage to objects on the earth's surface, especially buildings which may be subjected to pressures they were not designed to resist. Earthquakes are commonly caused by the sudden movement of tectonic plates under the earth's surface. They can also be caused volcanically, as magma moves beneath the earth's surface, causing vibrations or tremors at the earth's surface [1]..

Earthquakes occur in various places around the world, but some areas have a greater earthquake potential than others due to local geographic conditions West Sumatra is one such region [2].. West Sumatra is vulnerable to volcanic earthquakes because of several active volcanoes in the region. Three volcanoes - Mount Marapi in Agam Regency, Mount Talang in Solok Regency, and Mount Tandikat in Padang Panjang City - are the main causes of volcanic earthquakes in the West Sumatra region in recent times.

Besides volcanic earthquakes, West Sumatra is also frequently hit by tectonic earthquakes. The region is flanked by two earthquake lines, namely the plate subduction zone in the western sea area and the Sumatran fault zone (Semangko fault), located along with the hill range (Bukit Barisan) [3].. Tectonic earthquakes are generally stronger and more dangerous than volcanic earthquakes [4].. Tectonic earthquakes occurring below sea level also have the potential to generate tsunamis that can lead to even greater damage.

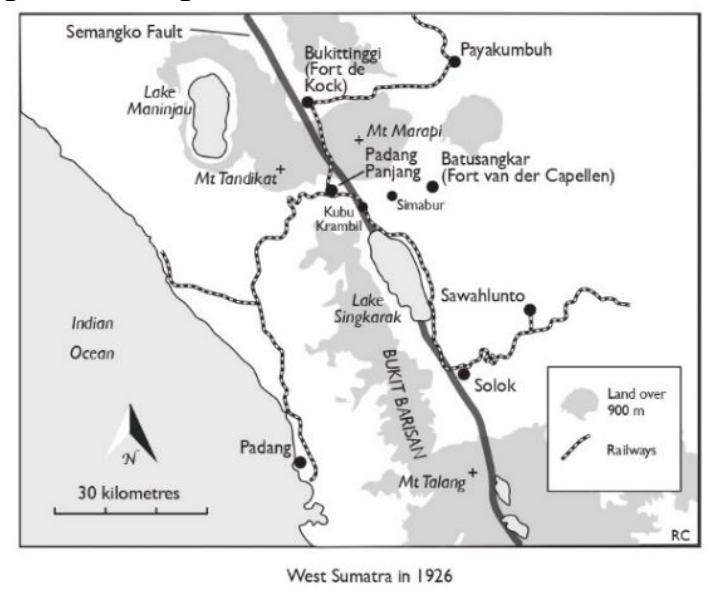

Fig. 1. West Sumatra Map in 1926

The oldest manuscript that records an earthquake in the West Sumatra region is the Du Puy report in 1845. James du Puy was the Dutch resident, or local governor, in Padang. In his report, he wrote about an earthquake in 1797 which hit the Padang City area. This earthquake occurred on 10 February 1797 at ten o'clock at night. The earthquake then triggered a tsunami wave that destroyed parts of the city of Padang. In another report in 1847 , Du Puy also mentioned an earthquake forty years earlier in 1757 that shook the city of Padang causing massive destruction and resulting in the

* Corresponding author: yenny.narny01@gmail.com 
land being torn apart [5]. This earthquake is the oldest disaster recorded in the historical records of West Sumatra, although not much information can be gathered for further study.

In the following years, various areas in the province of West Sumatra were repeatedly hit by earthquakes, causing the destruction of landscapes and buildings and claiming many lives. It was recorded that there were about 15 earthquakes with a significant intensity that caused devastation in various areas of West Sumatra from 1797 to 2010. The intensity of these earthquakes ranged between 5 and 8.5 on the Richter Scale. Some earthquakes triggered tsunami waves to cause even more enormous damage in this region6].

At the beginning of the 20th century, West Sumatra underwent both a socio-political transformation and a conflict with modernity. This transformation prevailed not only in big cities but also in remote villages. On the other hand, in the main cities in West Sumatra, political and social movements emerged. At this time, in the city of Padang Panjang, known as one of the centres of education in the region, many schools, and office buildings were built as well as public facilities such as hospitals and train stations. Padang Panjang was one of the important cities until an earthquake that struck in 1926 devastated the city. The earthquake not only claimed many lives but also caused enormous material losses.

The magnitude of the devastation caused by the earthquake attracted wide attention from newspapers circulating at that time. Their reports describing the devastation generated sympathy from both within and outside the colony. To restore the situation to normal, the colonial government then provided various forms of aid for earthquake victims. This study focuses on how the colonial government handled the social and economic consequences of the 1926 earthquake as well as the narratives about the earthquake that appeared in the local printed mass media.

\section{Data Source}

This paper utilizes various sources of print media published at the time of the earthquake. Other written sources were also obtained from the National Archives of the Republic of Indonesia. These sources were then studied to obtain data used to reconstruct historical events related to the earthquake that hit the Padang Panjang area in 1926. These data can be classified into two parts according to types and sources. There are four types of data. First is data on the causes of the earthquake obtained from the newspapers $D e$ Maasbode on 29 June 1926 and Deli Courant on 3 July 1926. Both newspapers were in the Dutch language.

The second type of data is on the damage caused. For this type of data, the sources are provided by newspapers and magazines written in both Dutch and Indonesian language. Among the newspapers and magazines were Iqbalul Haq magazine, June-July 1926 Edition, Barito Minangkabau magazine 10 July 1926, Deli Courant 3 July
1926, Dagblad Radio 29 June 1926, and Soera Kota Gedang 7 July 1926.

Third, data for casualties and material losses were obtained from magazines and archives such as Dagblad Radio 29 June 1926, Soera Kota Gedang 7 July 1926, and Iqbalul Haq magazine Edition June-July 1926 Zutphensche Courant 20 August 1926 and ANRI, AG archives July 3, 1926, No. 18679.

Fourth, for material losses and government policies, data are obtained from archives and newspapers such as; archive ANRI, AG 3 July 1926, No. 18679, Oetoesan Sumatra 11 November 1926, ANRI archives, AG 3 July 1926, No. 18679, De Telegraaf 3 July 1926, Soeara Kota Gedang 7 July 1926, ANRI, BGS July 2, 1926, No. 1224, ANRI archives, Tel 24 July 1926, No. 521ª, Grote Bundels.

\section{Method}

This paper employs the 4 stage- historical method, namely:

1. Heuristics or data collection stage. The data supporting this article were obtained from various libraries in West Sumatra, and the National Archives in Jakarta. The library collection included various contemporary newspaper articles and documents discussing the earthquake that occurred in Padang Panjang in 1926.

2. Criticism, namely the stage where all sources that have been collected are checked and verified for accucracy and correctness so that the data obtained are valid to be used as sources of writing.

3. Interpretation, which is the stage where the data that has been collected and criticized are combined into a unified understanding through one historical concept so that these data provide various historical facts about the earthquake of 1926 .

4. Historiography, that is, the final stage of the historical research method, namely writing what is understood as a historical reality based on the facts found and explained as a valuable reconstruction effort of the past.

\section{Discussion}

The earthquake of Padang Panjang occurred on Monday, 28 June 1926. This earthquake coincided with the day of the city market day, with the consequence that most of the people at the time of the earthquake were in the Pasar Serikat of Padang Panjang Batipuh, X Koto. These marketgoers were busy buying and selling or just looking around and sitting and relaxing at coffee shops[7].

The earthquake hit with two large quakes and many aftershocks of small earthquakes. The first earthquake had a strength of $\mathrm{Ms}=6.75$ while the second earthquake had a strength of $\mathrm{Ms}=6.5[8]$. The first earthquake was felt at 10 in the morning, amid the hustle and bustle of the city market, full of people buying and selling in the market. All of a 
sudden, there was a very strong quake that caused people to rush out of their homes or buildings to reach open spaces. The second earthquake occurred at around 1 in the afternoon with a strength almost the same as that of the first earthquake. The community continued to experience after shakes until 7 July. During this time, the sun was blocked by thick clouds, intermittently accompanied by drizzle. The sunlight entering the earth is blurred and dim. Cahaya matahari yang masuk ke bumi tidak sempurna, remangremang. The dim light of the sun during these earthquakes also created a tense atmosphere and created a sense of fear that would never fade away from people's hearts and minds [9].

Muhammad Radjab, a well-known journalist from West Sumatra, describes in his autobiography how the community reacted when the earthquake hit the city. He reports that several people chanted the words La ilaha illallah ("There is none worthy of worship except Allah) continuously in the hope that if they died they would do so while chanting and reciting this sentence affirming tawhed (the oneness of Allah). He also described how most people chose to take refuge in a surau, an Islamic assembly building in some regions of Sumatra and the Malay Peninsula used for worship and religious instruction and usually smaller than a mosque. On the other hand, his father, who was an ulema, lectured the gathered people, "We must tawakkal, [the word for the Islamic concept of the reliance on God].. The world might end in a few days. Humans have been evil many times, therefore it is in the law of God.'[10].

The earthquake destroyed several areas in West Sumatra and caused many casualties and enormous material losses. Padang Panjang and surrounding areas suffered the most from the earthquake. Nonetheless, the impact of this powerful earthquake was also felt in Padang, Solok, Agam, Bukittinggi, Payakumbuh, and Batu Sangkar [11].

The cause of the earthquake was initially thought to be volcanic activity from Mount Talang [12]. However, further investigation by Dr. S.W. Visser, a scientific collaborator at the Koninklijk Magnetisch en Meteorologisch Observatory (KMMO) led to a different insight. The KMMO was founded by the Netherlands government that to research meteorology, but its investigations later extended to the phenomenon of earthquakes. The colonial government, conscious that the Dutch East Indies region as a whole was vulnerable to earthquakes, both volcanic and tectonic. For this reason, they set up an institution in charge of researching various earthquake phenomena. On January 1, 1866, the Koninklijk Magnetischen Meteorologisch Observatorium te Batavia (KMMO) was established which was the forerunner of the birth of BMKG (Badan Meteorology, Climatology, and Geophysics). Initially, this institution researched the measurement of temperature, atmospheric pressure, wind speed and direction, duration and intensity of the sun, as well as measurements of rainfall [31].. However, in 1908 this institution began to research earthquakes, notably by installing horizontal components of the Wiechert seismograph in Jakarta, while the installation of vertical components was only carried out in 1928. In the previous year, 1907, the government had first placed these devices in the Ambon and Padang areas. However, these devices could not function properly so they were brought back to Batavia [32].. Visser found that the earthquake was tectonic. According to him, the earthquake was caused by fractures in the earth's crust that stretched along the Bukit Barisan [13]..

As a result of the earthquake, the city of Padang Panjang which had been a center of trade, education, railway transportation, and political and religious movements was destroyed in an instant. Impressive buildings that had adorned the city, ranging from shop buildings, houses, schools (both religious and government), to mosques and surau were destroyed [14].. Buildings made of stone were almost all destroyed. On the other hand, buildings made of wood were often in better condition, although dozens of them also collapsed in the earthquake. The train station was also badly damaged, the roof of the centre, as well as some walls, had collapsed, while large cracks could be seen everywhere [15]. The fact that the destruction was most severe in cities, where communists, reformist madrasas (Islamic schools), and colonial administrators lived, led traditional or conservative Muslim clergy to view the earthquake as divine retribution against impious modern institutions [16].

Losses due to the earthquake are estimated to have reached ten million guilders for the entire region of West Sumatra. Meanwhile, in downtown Padang Panjang, the loss was estimated at $\mathrm{f}$ [or $f]$. 574,000, while the total loss in the Padang Panjang area as a whole reached $\mathrm{f} 1,175,000$ due to damage and destruction of various community properties. Other areas outside Padang Panjang such as Fort de Kock (Bukittinggi) and Solok suffered losses of $\mathrm{f}$ 200,000 and $f 632,000$, respectively [17].

Not only did the earthquake destroy built infrastructure, but it also caused damage to the ecosystem and natural environment. The earthquake caused many roads to crack as wide as three to five centimeters. Besides that, the earthquake also caused landslides in Padang Panjang, Kubu Krambil, and Simabur. Some of the environment around Lake Singkarak also suffered severe damage because the earthquake caused the lake water to overflow which then flooded the surrounding area [18].

The earthquake also led to the complete paralysis of various economic activities of the community. To meet basic needs such as food, medicine, and clean water, the community heavily relied on assistance from various parties, both private and colonial government. Even though at that time there were also some people selling food ingredients, the prices were too high for people who had just survived the earthquake, so that the government and the private sector offered significant help with food assistance [19].

The number of people who died as a result of the earthquake is estimated to have reached a thousand victims in the entire region of West Sumatra [20]. In Padang 
Panjang, the death toll from the earthquake was estimated at 195 people (other opinions put the death toll at around two hundred or three hundred). The toll may have been higher because the actual number of victims could not be identified due to limited information at the time. Of the 195 earthquake victims in Padang Panjang, 170 victims were from the Minangkabau community, 23 victims from the Chinese community, and one each from the Europeans and Bombay (British Indian) communities. The earthquake also caused many houses to be destroyed. It is estimated that as many as 7,000 people were forced to live in refugee camps set up by the government in a field. The earthquake victims later faced new problems such as lack of clean water, food, and medicine so that on 29 June the government immediately sent aid to ease the suffering of the earthquake victims [21].

The Chinese community was the second most disadvantaged party in the disaster. There was much destruction in the Chinese residential area in Padang Panjang, causing many casualties and enormous material losses. Meanwhile, only a single fatality from among the Europeans was reported in various newspapers (especially Dutch-language newspapers) at that time. The victim was an aide and pharmacist named Schmidt who died when he was buried under the rubble of a collapsed building. It was also reported that an infantry lieutenant named E.J. Donk suffered serious injuries and an officer named Kist suffered minor injuries. The other Europeans who managed to survive took refuge in emergency tents set up in the middle of the market [22].

In dealing with the earthquake, the Padang Panjang municipal government continued to send the latest information to the colonial central government in Bogor via telegram. These telegrams were then distributed to various relevant government institutions such as Binnenlands Bestuur (Department of Home Affairs), Leger (Army), BOW (Department of Public Works), Gouvernementsbedrijven or related government bodies [23]. To respond to the emergency arising from the earthquake in West Sumatra, the colonial central government immediately dispatched military troops to assist earthquake victims and secure the surrounding area on 3 July 1926. The government also sent food aid which was distributed to all areas affected by the earthquake [24].

Reporting about the earthquake and its aftermath in various newspapers attracted much attention and sympathy from within and outside the country, with the result that assistance also came from private parties. One of the private parties that assisted was Smeroefonds, a foundation that was established in 1911 in Batavia in response to a volcanic eruption in Java and which subsequently became the most important and private organization offering disaster relief. and specialized in assisting disaster victims [25]. Assistance also came from various Minangkabau associations located abroad such as Studyfonds Kota Gedang, Tjabang Betawi [26]. Foreign aid came from a visit by the Swedish Consul General [27]. and aid from Sydney of one million pounds which arrived on 24 July 1926 [28].
For the community to return to normal activities, the colonial government then carried out repairs to various infrastructures that had been damaged by the earthquake. The main repairs were carried out on the houses of government officials and public facilities; these repairs were targeted to be completed in 1927 . The main targets for the repairs carried out by the government were the houses of officials destroyed by the earthquake so that they could immediately resume their state duties. For the construction of these official houses, the government received direct financial support from the Kingdom of the Netherlands in two payments of 162,500 guilders and 38,000 guilders. On the other hand, various public facilities such as railway stations and lines, hospitals, post offices, and so on were also a major focus of the government so that the city of Padang Panjang as a whole could rapidly return to normal activities. [29].

In the various policies taken by the colonial government, there was a tendency to prioritize the safety of the Europeans ahead of that of the natives. This priority was indicated in the reports made by Residents, in which they addressed the safety of their officials and employees rather than that of the indigenous people who had suffered more from the earthquake. The government also based its priority on the restoration of various infrastructures based on economic interests by prioritizing the improvement of transportation and communication routes. Restoring these lines of communication meant that the flow of income from the West Sumatra region could be restored for the benefit of the colonial government [30].

On the other hand, the KMMO prioritized scientific research and encouraged its employees to publish the results of their research. In 1911 KMMO began to publish its scientific journal, which was published every year and contained writings about the various studies they carried out [33]. However, the knowledge about earthquakes collected by this institution did not seem to have been widely disseminated so that most people were still very unaware of the earthquake that occurred. Lack of public understanding of the phenomenon of earthquakes contributed to the huge number of casualties and material losses as happened in Padang Panjang in 1926.

\section{Conclusion}

The large number of casualties and material losses caused by the earthquake of 1926 in Padang Panjang demonstrated the lack of public knowledge in dealing with the earthquake that occurred so that a high number of losses could not be prevented or minimized. Muslim society in West Sumatra at that time generally considered the earthquake as the coming of the apocalypse sent by God as a result of the sins of the community. As a result, in dealing with the earthquake, they could only surrender and pray for a miracle without making any preparations to prevent greater losses when the aftershakes occurred. 
The colonial government played an important role in dealing with the earthquake and in restoring the facilities, infrastructures as well as the community who were suffering from the earthquake. Even though the policies taken were based on economic motives and the benefits that would be obtained by the colonial government, the humanitarian side was also seen from a large amount of government assistance to the community and infrastructure improvements to restore conditions in Padang Panjang to their original state. Moreover, the colonial government at that time also played a role in the development of science regarding the phenomenon of earthquakes in Indonesia in the long term through its institutions, so that losses due to earthquakes could be minimized in the future.

\section{References}

1. Sunarjo et.al, Earthquake Popular Edition, (Jakarta: Meteorology Climatology and Geophysics Council, 2012), 26, (2012)

2. S. Karim, Geography of West Sumatra and Earthquake Natural Disaster, Conference Paper Seminar on Natural Disasters, 2, (2011)

3. D. Surjo at.al, History of Earthquake Disaster in Sumatra, (Jakarta: Ministry of Education and Culture, 2016), 99, (2016)

4. Nur Hidayat dan Eko Widi Santoso, "Earthquake and its Mechanism”, Natural Journal, 2, 3, 50.

5. D Surjo et.al, op,cit, hlm. 101.

6. Ibid, 100 .

7. Mestika Zed, Final Report of the Professor's Research: Inventory and Reconstruction of the History of the September 30, 2009 Earthquake in the City of Padang Through Documentary Films, (Padang: Padang State University, 2012), 36, (2012)

8. Untung et.al, Rupture along the Great Sumatran Fault, Indonesia during the Earthquake of 1926 and 1943, Bulletin of the Seismological Society of America, 75, 1, 316.

9. Majalah Iqbalul Haq, June-July (1926)
10. Muhammad Radjab, Childhood in the Village 19131928: Autobiography of a Minangkabau Child, (Jakarta: Library, 1974), 128, (1974)

11. Magazine Berito Minangkabau 10 July 1926

12. De Maasbode 29 June 1926

13. Deli Courant 3 July 1926

14. Magazine Iqbalul Haq, op,cit.

15. Deli Courant, op,cit.

16. Jeffrey Hadler, The Endless Dispute: Matriarchy, Islamic Reformism, and Colonialism in Minangkabau, (Jakarta: Freedom Institut, 2010), 245, (2010)

17. Zutphensche courant 20 August 1926

18. Dagblad Radio 29 Juni 1926 and Soera Kota Gedang 7 July 1926

19. ANRI, AG 3 July 1926, No. 18679

20. Dagblad Radio dan Soeara Kota Gedang, op,cit.

21. Magazine Iqbalul Haq, op,cit.

22. Nieuwsblad van Friesland: Hepkema's courant 2 July 1926

23. ANRI, AG 30 June 1926, No. 18284

24. ANRI, AG 3 July 1926, No. 18679

25. De Telegraaf 3 July 1926; Sander Tetteroo, 'Java, 1919: Colonial Disaster Relief', Online Atlas on the History of Humanitarianism and Human Rights, https://hhratlas.ieg-mainz.de/articles/tetteroo-java

26. Soeara Kota Gedang, op,cit.,

27. ANRI, BGS 2 July 1926, No. 1224.

28. ANRI, Tel 24 July 1926, No. 521a, Grote Bundels.

29. Oetoesan Sumatra 11 November 1926.

30. Devi Riskianingrum, 'Disaster Management and Knowledge Transformation on Earthquake in the Colonial Period', Jurnal Paramita 23, 1, 6.

31. K. van Berkel et.al, A History of Science in the Netherlands: Survey, Themes, and Reference, (Leiden: Brill, 1999), 223-224, (1999)

32. J. Paulus et.al, Encyclopaedie van Nederlandsch-Indie, Eerste Deel, (Leiden: E.J Brill, 1918), 55-59, (1918)

33. Van Berkel, op, cit, 224-225. 